\title{
Antenatal diagnosis of Krabbe's leucodystrophy: enzymatic and morphological confirmation in an affected fetus
}

\author{
D. F. F A R R E L , S. M. S U M I, C.R. S C O T T, A N D G R I C E \\ From the Division of Neurology, Laboratory of Neuropathology, Department of Pathology, \\ Department of Pediatrics, and the Child Development and Mental Retardation Center, \\ University of Washington School of Medicine, Seattle, Washington, USA
}

S UMMARY Galactosylceramide $\beta$-galactosidase activity was assayed in cultured amniotic fluid cells from two pregnancies at risk for Krabbe's leucodystrophy. The elective termination of one pregnancy was carried out after demonstration of a severe deficiency of galactosylceramide $\beta$-galactosidase activity. The diagnosis of Krabbe's leucodystrophy in the affected fetus was confirmed enzymatically by a deficiency of galactosylceramide ß-galactosidase in brain, liver, kidney, and cultured skin fibroblasts, and histologically by the ultrastructural demonstration of the typical intracellular inclusions in cells of the spinal cord.

Krabbe's (globoid cell) leucodystrophy is an inherited metabolic disorder of galactolipid catabolism which usually becomes symptomatic at six months of age. The clinical course is one of rapid deterioration ending in death by about two years. Pathologically, the disease is characterised by severe demyelination in both the central and peripheral nervous systems. Numerous giant multinucleated globoid cells $(30-40 \mu \mathrm{m})$, the characteristic histological feature of this disease, are usually found in close proximity to blood vessels of the central nervous system.

A deficiency of galactosylceramide $\beta$-galactosidase activity has been found in all tissues from affected infants (Suzuki and Suzuki, 1970; Svennerholm et al., 1975). Obligate heterozygotes have been shown to have intermediate levels of galactosylceramide $\beta$-galactosidase activity both in cultured skin fibroblasts (Suzuki and Suzuki, 1971; Farrell et al., 1973a), and in white blood cells (Suzuki and Suzuki, 1971). Cultured amniotic fluid cells obtained between 14 and 18 weeks gestation have levels of galactosylceramide $\beta$ galactosidase activity comparable to those found

Supported in part by a USPHS Grant HD-04665, Basil O'Connor Starter Research Grant from the National Foundation (DFF), and USPHS Center Grant HD-610956.

Address for reprint requests: Dr Donald F. Farrell, Division of Neurology (RG-20), University of Washington School of Medicine, Seattle, Washington 98195, USA.

Accepted 15 July 1977 in cultured skin fibroblasts (Farrell et al., 1973a) The antenatal diagnosis and confirmation of 0 Krabbe's leucodystrophy in one fetus has been reported (Suzuki et al., 1971; Ellis et al., 1973). Wenger et al. (1974) reported a marked deficiency of galactosylceramide $\beta$-galactosidase in pregnancye at risk for Krabbe's disease; but the family chose not to terminate the pregnancy and no confirmation of the diagnosis was provided.

Cultured amniotic fluid cells from two pregnancies at risk for Krabbe's leucodystrophy have been studied in our laboratory. In one culture galactosylceramide $\beta$-galactosidase activity was normal, while in the other there was a marked deficiency of this enzyme.

\section{Case reports}

FAMILY 1

Nonconsanguineous parents had two babies who died with Krabbe's leucodystrophy-confirmed pathologically and enzymatically. A marked deficiency of galactosylceramide $\beta$-galactosidase activity was demonstrated in cultured skin fibroblasts from their second affected infant, while cultured skin fibroblasts from each parent had intermediate values of activity of this enzyme.

A transabdominal amniocentesis was performed in the 16th week of the mother's pregnancy, and $20 \mathrm{ml}$ of amniotic fluid was obtained. Cultured amniotic fluid cells were assayed for galacto- 
sylceramide $\beta$-galactosidase activity, and an enzyme value twice that of either of the parents was found, suggesting that this fetus was unaffected.

\section{FAMILY 2}

The first baby born to these parents died at 6 months of age and had both an enzymatic and pathological diagnosis of Krabbe's leucodystrophy. Each parent was shown to have an intermediate value for galactosylceramide $\beta$-galactosidase activity in cultured skin fibroblasts. During the 13 th week of the third pregnancy a transabdominal amniocentesis was performed, and $20 \mathrm{ml}$ of amniotic fluid was removed and cultured. The cultured amniotic fluid cells were harvested and assayed for galactosylceramide $\beta$-galactosidase activity. Additional cultured amniotic fluid cells were examined three days later, and a marked deficiency of galactosylceramide $\beta$-galactosidase activity was demonstrated on both occasions. The pregnancy was then terminated by induction with prostaglandin $\left(\mathrm{PGE}_{2}\right)$.

\section{Methods}

The affected fetus had a crown-rump length of $163 \mathrm{~mm}$, a foot length of $38 \mathrm{~mm}$, and a weight of 427 grams. These measurements are consistent with the estimated gestational age of 18 weeks (Birkbeck et al., 1975). Specimens of lung and skin were taken for culture. Tissue specimens from brain, spinal cord, and peripheral nerve were processed for histological and electron microscopic study. The remainder of the tissues from the nervous system as well as the liver and kidneys were frozen in dry ice and stored in airtight sealed plastic containers at $-70^{\circ} \mathrm{C}$ for enzymatic and chemical analysis. Control tissues were obtained at necropsy and stored under the same conditions as above.

Fibroblast and amniotic fluid cell cultures were grown and harvested as previously reported (Farrell et al., 1973a; Chen et al., 1975) except that the amniotic fluid cells were established in culture without preliminary centrifugation.

Galactosylceramide $\beta$-galactosidase activity was assayed with authentic $\left(6^{3} \mathrm{H}\right)$-galactosylceramide by the method of Farrell et al. (1973a) with the following modifications: the reaction was stopped by placing the assay tubes in an ice-water bath. Deionised water $(0.8 \mathrm{ml})$ containing $1 \mathrm{mg}$ of 'carrier' galactose was added, followed by $0.1 \mathrm{ml}$ of $10 \%$ bovine serum albumin and $0.1 \mathrm{ml}$ of $100 \%$ trichloroacetic acid, mixed and then centrifuged in a MSE centrifuge at $1500 \mathrm{rpm}$ for 10 minutes. One millilitre of clear supernate was removed and extracted with an equal volume of diethyl ether to remove the trichloroacetic acid: $0.5 \mathrm{ml}$ of the aqueous phase was placed in a scintillation vial and taken to dryness to remove any possible trace of the diethyl ether. Deionised water $(0.5 \mathrm{ml})$ and $15 \mathrm{ml}$ of Aquasol (New England Nuclear) were added to the scintillation vial, and the radioactive galactose was assayed by liquid scintillation spectroscopy.

Arylsulphatase $\mathrm{A}$ and $p$-nitrophenyl $\beta$-galactosidase activities were assayed by the method previously reported (Farrell et al., 1973b). Total $p$-nitrophenyl $\beta$-N-acetyl hexosaminidase activity was assayed by the method of Okada and O'Brien (1969).

Portions of the cerebrum, brainstem, cerebellum, spinal cord, and one sciatic nerve were also fixed in buffered glutaraldehyde, processed for embedding in epoxy epon, and the sections stained with lead hydroxide and uranyl acetate for electron microscopy.

\section{Results}

Galactosylceramide $\beta$-galactosidase activity in amniotic fluid cells from pregnancies at risk for Krabbe's disease are shown in Table 1. In family 1 , the specific activity for galactosylceramide $\beta$ galactosidase was almost twice that of either heterozygous parent. We thought that this enzyme activity represented either a low normal value or a high heterozygote value, and recommended that the pregnancy continue. Skin fibroblasts cultured from a $2 \mathrm{~mm}$ skin punch biopsy sample from this same newborn infant after a normal delivery contained a normal galactosylceramide $\beta$-galactosidase

Table 1 Galactosylceramide $\beta$-galactosidase activity* in cultured skin fibroblasts and cultured amniotic fluid cells

\begin{tabular}{|c|c|c|}
\hline Enzyme source & Cell lines & $\begin{array}{l}\text { Galactosylceramide } \\
\beta \text {-galactosidase } \\
(\text { mean } \pm S D)\end{array}$ \\
\hline $\begin{array}{l}\text { Control fibroblasts } \\
\text { Control amniotic fluid cells } \\
\text { Obligate heterozygote GLD } \\
\text { fibroblasts } \\
\text { GLD fibroblasts } \\
\text { Family 1 } \\
\text { Mother-fibroblasts } \\
\text { Father-fibroblasts } \\
\text { Amniotic fluid cells } \dagger \\
\text { Fullerm infant skin fibroblasts } \\
\text { Family } 2 \text {-fibroblasts } \\
\text { Mother-fibroblasts } \\
\text { Father-fibroblic fluid cells } \dagger \\
\text { Amniotic }\end{array}$ & $\begin{array}{l}(37) \\
(7) \\
(16) \\
(9) \\
(1) \\
(1) \\
(1) \\
(1) \\
(1) \\
(1) \\
(1)\end{array}$ & $\begin{array}{l}2.26 \pm 0.97 \\
2.30 \pm 0.94 \\
0.85 \pm 0.18 \\
0.05 \pm 0.009 \\
0.68 \\
0.82 \\
1.40,1.32 \\
1.74 \\
0.65 \\
0.68 \\
0.1,0.09,0.07\end{array}$ \\
\hline
\end{tabular}

*Specific activity-n moles substrate hydrolysed/hr/mg of protein. +Average specific activities, duplicate determinations. 
activity. Over the subsequent two years the development of this infant has been normal.

Galactosylceramide $\beta$-galactosidase activity in the amniotic fluid cells from the third pregnancy in family 2 showed a marked deficiency of galactosylceramide $\beta$-galactosidase. As shown in Table 1 , the enzyme activity was approximately $4 \%$ that of control amniotic fluid cells and $12 \%$ of the parents' enzyme activity.

Galactosylceramide $\beta$-galactosidase, arylsulphatase A, $p$-nitrophenyl $\beta$-galactosidase, and $p$ nitrophenyl $\beta$-N-acetylglucosaminidase activities were assayed in brain, liver, kidney, and cultured skin fibroblasts (Table 2) from the affected fetus. Galactosylceramide $\beta$-galactosidase activity was deficient in all organs examined with enzyme activities falling between 3 and $7 \%$ of controls. The galactosylceramide $\beta$-galactosidase activities in the tissues from the affected Krabbe's fetus were at the same level as found in tissues of older patients dying of Krabbe's leucodystrophy (Table 2).

Arylsulphatase $\mathrm{A}$ in brain homogenates was approximately $25 \%$ of controls, while in liver, kidney, and cultured skin fibroblasts the enzyme activity was closer to control values. The other two acid hydrolytic enzymes assayed in the affected fetus were similar to control levels.

The brain, spinal cord, and the sciatic nerve showed no obvious gross abnormality.

\section{LIGHT MICROSCOPY}

Multiple sections of the cerebrum, brainstem, cerebellum, spinal cord, and sciatic nerve were examined. Only in the spinal cord were PAS positive cells found. They were small, rather irregular in shape, and measured approximately 10-21 $\mu \mathrm{m}$ in diameter, the majority being less than $15 \mu \mathrm{m}$. They were found both near blood vessels and free in the white matter. Most of the cells containing PAS positive material were mononuclear, although a few appeared to be binucleated. These cells were restricted to the white matter, and appeared to be predominant in the dorsal and ventral columns of the spinal cord. Similar cells were not identified elsewhere in the nervous system, including the sciatic nerve.

\section{ELECTRON MICROSCOPY}

In the spinal nerve roots and the sciatic nerve many myelinated nerve fibres were present, but no definite abnormality was seen. In particular, we were unable to identify any cells with the characteristic paracrystalline inclusions previously described in peripheral nerves from patients with Krabbe's disease (Bischoff and Ulrich, 1969).

In the spinal cord white matter only a few myelinated fibres were present. However, several cells containing either curved or straight, tapering membrane-bound tubular inclusions were found (Fig. 1). They varied considerably, both in width and length. They measured approximately 44 to $290 \mathrm{~nm}$ at their widest points. They often branched or communicated with a neighbouring tubule. These tubules or spicules contained one or more thinner tubules formed by somewhap thinner membranes, measuring approximately 1 to $15 \mathrm{~nm}$. On cross-section (Fig. 1), the somewha马 round or oval outline of the cytoplasmic spicule containing one or several small oval tubulesc could be seen.

The identity of the cells containing tubular inclusions could not be definitely ascertained. They had no constant relationship to blood vessels. The cytoplasm was pale and contained several mitochondria, a well-developed endoplasmic reticulum and Golgi system, but filaments were inconspicuous. In some cells occasional lipid droplets and

Table 2 Enzyme specific activities* in various organs from the Krabbe's fetus

\begin{tabular}{|c|c|c|c|c|}
\hline Enzyme source $\dagger$ & $\begin{array}{l}\text { Galactosylceramide } \\
\beta \text {-galactosidase }\end{array}$ & $\begin{array}{l}\text { Arylsulphatase } \\
\text { A }\end{array}$ & $\begin{array}{l}\text { p-nitrophenyl } \\
\beta \text {-galactosidase }\end{array}$ & $\begin{array}{l}p-n i t r o p h e n y l \beta-N- \\
\text { acetylhexosaminidase }\end{array}$ \\
\hline \multicolumn{5}{|l|}{ Brain } \\
\hline Controls (7) & $0.794 \pm 0.27$ & $91 \pm 23$ & $153 \pm 26$ & $433 \pm 7.0$ \\
\hline Krabbe's leucodystrophy (5) & $0.016+0.02$ & & & \\
\hline $\begin{array}{l}\text { Krabbe's fetus } \\
\text { Liver }\end{array}$ & 0.032 & 25 & 176 & 441 \\
\hline \multicolumn{5}{|l|}{ Liver } \\
\hline $\begin{array}{l}\text { Controls (9) } \\
\text { Krabbe's (4) }\end{array}$ & $0.530 \pm 0.22$ & $76 \pm 5.4$ & $174 \pm 8$ & $345 \pm 24$ \\
\hline & $\begin{array}{l}0.014 \pm 0.006 \\
0.040\end{array}$ & & & \\
\hline & & 183 & 371 \\
\hline Controls (4) & $1.31+0.25$ & $72+8$ & $205+26$ & $394+18$ \\
\hline Krabbe's fetus; & 0.041 & 42 & 226 & $\begin{array}{l}394 \pm 18 \\
398\end{array}$ \\
\hline \multicolumn{5}{|l|}{ Skin fibroblasts } \\
\hline Controls (37) & $2.26 \div 0.97$ & $945 \pm 168$ & $1840 \pm 507$ & $5394 \pm 1164$ \\
\hline Krabbe's fetus & 0 & 1138 & 1914 & 6315 \\
\hline
\end{tabular}

*Specific activity-n moles substrate hydrolysed/hr/mg of protein.

†Duplicate determinations of multiple samples (mean $\pm \mathrm{SD}$ ).

¥Multiple determinations of fetal tissue sample (mean). 


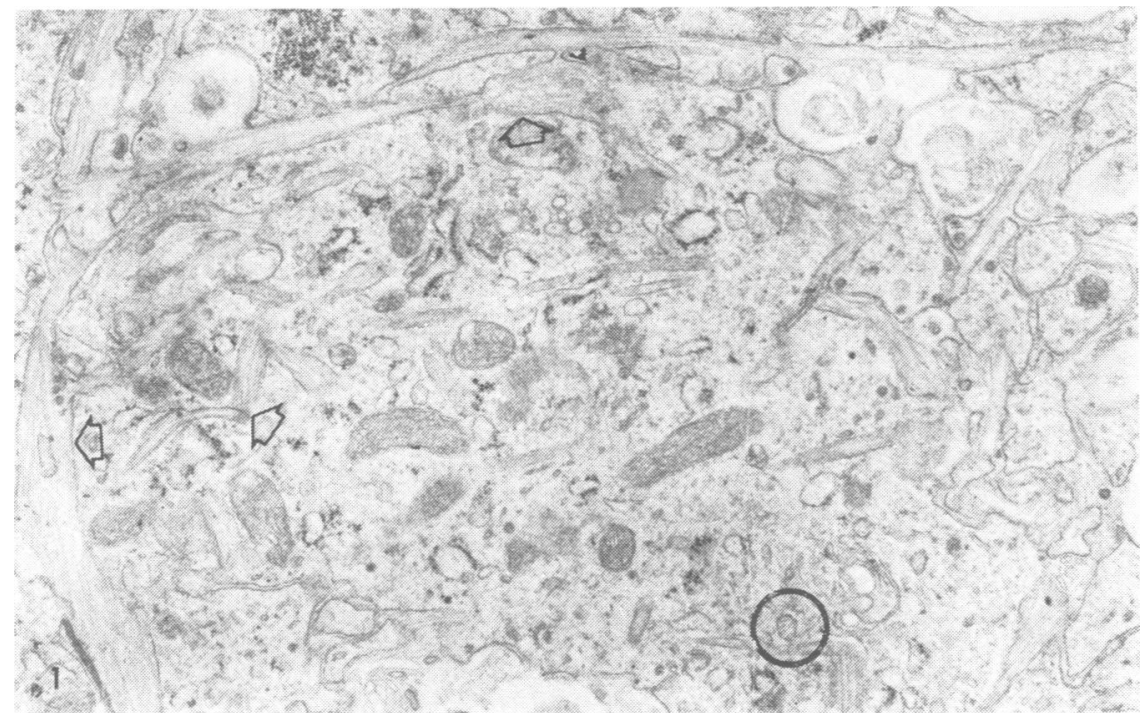

Fig. 1 Portion of cell containing numerous characteristic tubular or spicule-like inclusions (open arrows). Some tubules have open connections with adjacent tubules (arrow head). Most contain several smaller tubular structures, and one such is seen in cross-section (circle). $(\times 16500)$

irregular dense bodies were present. Although the cell margins were somewhat irregular, no definite pseudopodia or fingerlike processes were present. Their nuclei contained peripherally arranged chromatin, but an occasional nucleus had a large prominent nucleolus. As in the histological sections, most of the cells had only one nucleus. We did find one cell which appeared to have three nuclei (Fig. 2), and this cell measured approximately $16 \mu \mathrm{m}$ in size.

Several fibrillary astrocytes were also found in these sections. None of the astrocytes contained the tubular inclusions, and they could be readily distinguished from the Krabbe's cells.

\section{Discussion}

The antenatal diagnosis and confirmation of a case of Krabbe's leucodystrophy was established by the demonstration of a marked deficiency of galactosylceramide $\beta$-galactosidase in cultured amniotic fluid cells from a pregnancy at risk for this disease. As we reported earlier (Farrell et al., 1973a) and confirmed in this study, galactosylceramide $\beta$ galactosidase activity in cultured amniotic fluid cells is similar, if not identical, to the enzyme activity assayed in normal cultured skin fibroblasts. This is unlike the marked differences in arylsulphatase A activity reported in these same two cells (Kaback and Howell, 1970; Van der Hagen, 1973).
A marked deficiency of galactosylceramide $\beta$ galactosidase activity was found in brain, liver, kidney, and cultured skin fibroblasts confirming the enzymatic diagnosis of Krabbe's leucodystrophy in the affected fetus. The galactosylceramide $\beta$-galactosidase activities in all tissues from the affected fetus were comparable to the residual galactosylceramide $\beta$-galactosidase activities in tissues from infants dying of Krabbe's disease. The other acid hydrolytic enzymes were within the normal range of controls, except for brain arylsulphatase $\mathrm{A}$ which was about $25 \%$ of control levels. This finding of low arylsulphatase $A$ activity in fetal brain tissue is probably normal for this particular stage of development, and is assumed to reflect the developmental pattern of enzymatic activity associated with myelin formation, as has been well described in experimental animals (Bowen and Radin, 1969).

Wenger and colleagues (1974) have suggested that measurement of the activity of lactosylceramide $\beta$-galactosidase is a more sensitive method than the measurement of galactosylceramide $\beta$ galactosidase, and they have used this enzyme activity to diagnose Krabbe's leucodystrophy. The major problem in using lactosylceramide as the only substrate in the antenatal diagnosis of Krabbe's leucodystrophy comes from the demonstration that there are at least two genetically distinct enzymes which hydrolyse the galactose 


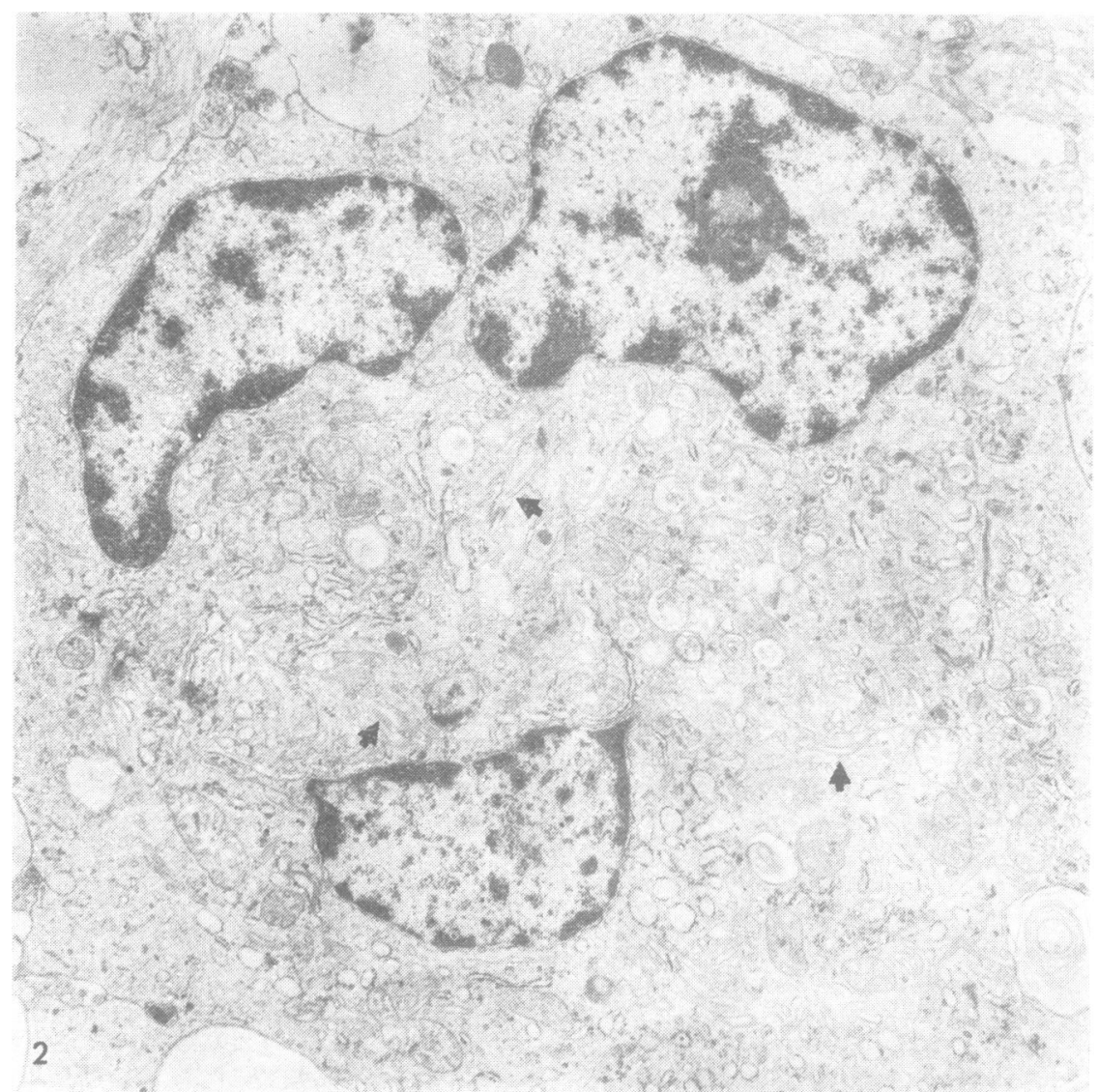

Fig. 2 Cell with three nuclei containing several characteristic tubules (arrows). $(\times 6000)$

moiety from lactosylceramide, but only one of these is related to Krabbe's leucodystrophy (Tanaka and Suzuki, 1975).

The selectivity of lactosylceramide $\beta$-galactosidase in measuring the deficient enzyme in Krabbe's leucodystrophy depends upon such factors as the purity of the detergent used (Callahan and Gerrie, 1975; Tanaka and Suzuki, 1975; Wenger et al., 1975), the concentration of the detergent (Kurczynski et al., 1976), and possibly the presence or absence of oleic acid (Wenger et al., 1975). Various ratios of activity of these two enzymes towards lactosylceramide can occur with relatively minor changes in the reaction mixture, and, these therefore, might cause an erroneous result. The measurement of lactosylceramide $\beta$-galactosidase may be a useful adjunct in the diagnosis of Krabbe's leucodystrophy, but, because of the above problems, we suggest that galactosylceramide $\beta$-galactosidase activity should be the enzymatic basis for the diagnosis of this disease.

Morphological confirmation of the specific leucodystrophies in fetal tissues offers a special diagnostic problem since at this early developmental age very little myelination has occurred. Ellis et al. (1973) have described numerous small 15 to $25 \mu \mathrm{m}$ epitheloid-globoid cells and reactive astrocytes in the entire spinal cord from an affected fetus with Krabbe's disease. The fetus which we studied was three to four weeks younger, and the changes by light microscopy were not as distinct as in the older fetus. There were a few PAS-positive cells scattered throughout the white matter of the spinal cord. These were small, usually mononuclear, and irregular in shape. It was often difficult to distinguish them from astrocytes. Thus, none of the PAS-positive cells were readily recognised as epitheloid or globoid cells by light microscopy. We presume that many of these 
small PAS-positive cells were the precursors of typical globoid cells. Electron microscopically, one multinucleated cell was found, and tubular cytoplasmic inclusions characteristic of Krabbe's disease were seen in this cell in addition to being present in many of the smaller cells. The morphological differences of the present case from the earlier reported case (Ellis et al., 1973) appear to be related to the age of the fetus at the time of the termination of the pregnancy, and not to any qualitative difference in the disease process. Thus, in both fetal cases the typical large 20-40 $\mu \mathrm{m}$ multinucleated globoid cells of Krabbe's disease were not seen. As in the fetus reported by Ellis et al. (1973), we also found only straight or curved tubules in these cells. Most of our large tapering spicule-like inclusions contained one or more thin long tubules, and on cross-section both the outer larger spicules and their enclosed thin tubules were oval to slightly angular in shape, as previously described in older infants (Yunis and Lee, 1969; Andrews and Cancilla, 1970; Shaw and Carlson, 1970; Suzuki and Grover, 1970). These differences again probably reflect the extremely young age of the affected fetus and suggest that the crystalloid tubules may evolve from these tubule-containing spicules.

Although myelination was more advanced in the spinal nerve roots and the sciatic nerve, typical inclusions (Bischoff and Ulrich, 1969) could not be identified in any cells of the peripheral nerves. Thus, despite this earlier formation, the degeneration of peripheral myelin must occur after that of central myelin as suggested also by the later appearance of peripheral neuropathy in the affected chilaren (Dunn et al., 1969).

The morphological confirmation of the fetus with either globoid cell leucodystrophy or metachromatic leucodystrophy (LeRoy et al., 1973) appears to be much more difficult than the morphological confirmation of the gangliosidoses (Percy et al., 1973; Adachi and Volk, 1975). Abnormal neuronal cytoplasmic inclusions have been recognised in fetal spinal cord and dorsal root ganglia in Tay-Sachs disease as early as 12 weeks gestation (Adachi and Volk, 1975).

Svennerholm et al. (1975) have recently examined amniotic fluid cells from nine pregnancies at risk for Krabbe's disease and found no galactosylceramide $\beta$-galactosidasc values under $30 \%$ of the mean of their controls, and they have recommended continuance of the pregnancies. This group suggested that a fetus should have less than $20 \%$ of normal galactosylceramide $\beta$-galactosidase activity for the diagnosis of Krabbe's leucodystrophy. The amniotic fluid cells from the previously reported case had a galactosylceramide $\beta$-galactosidase activity which was $5 \%$ of control (Suzuki et al., 1971) while the present case had a mean of $4 \%$ of control activity. The individual determinations in our case ranged from 2 to $8 \%$ of the control mean. We believe that a galactosylceramide $\beta$-galactosidase activity of $20 \%$ of control is too high a value to be used to identify an affected Krabbe's fetus. Theoretically, it would be possible to abort a small percentage (approximately $2-3 \%$ ) of phenotypically normal heterozygotes if the diagnosis of Krabbe's leucodystrophy were arbitrarily established at $20 \%$ of control values. Since heterozygous values for galactosylceramide $\beta$-galactosidase have yet to be established for cultured amniotic fluid cells, and neither of the affected fetuses have had enzyme values above $10 \%$ of control, we feel that the diagnostic range of galactosylceramide $\beta$-galactosidase should be $10 \%$ or less for the antenatal diagnosis of Krabbe's disease.

\section{References}

Adachi, M., and Volk. B.M. (1975). Pathology. In The Gangliosidoses. Pp. 125-158. Edited by B. W. Volk and L. Schneck. Plenum: New York.

Andrews, J. M., and Cancilla, P. A. (1970). Cytoplasmic inclusions in human globoid cell leukodystrophy (Krabbe's disease). Ultrastructural and histochemical findings. Brain. 92, 861-870.

Birkbeck. J. A., Billewicz, W. Z., and Thomson, A. M. (1975). Foetal growth from 50 to 150 days of gestation. Annals of Human Biology, 2, 319-326.

Bischoff, A., and Ulrich, J. (1969). Peripheral neuicpathy in globoid cell leukodystrophy (Krabbc's disease): ultrastructural and histochemical findings. Brain. 92, 861-870.

Bowen, D. M., and Radin, N. S. (1969). Cerebroside galactosidase: a method for determination and a comparison with other lysosomal enzymes in developing rat brain. Journal of Neurochemistry, 16, 501-511.

Callahan, J. W., and Gerrie, J. (1975). Purification of $\mathrm{G}_{\mathrm{M} 1}$ ganglioside and ceramide lactoside $\beta$-galactosiclase from rabbit brain. Biochimica et Biophysica Acta, 391, 141-153.

Chen, S. H., Scott, C. R., and Swedberg. K. R. (1975). Heterogeneity for adenosine deaminase deficiency: expression of the enzyme in cultured skin fibroblasts and amniotic fluid cells. American Journal of Human Genetics, 27, 46-52.

Dunn. H. G., Lake, B. D., Dolman, C. L. and IVilson, J. (1969). The neuropathy of Krabbe's infantile cerebral sclerosis (globoid cell leukodystrophy). Brain. 92, 329-344.

Ellis, W. G., Schneider, E. L., McCulloch. J. R., Suzuki. K. and Epstein, C. J. (1973). Fetal globoid cell leukodystrophy (Krabbe's disease). Archives of Neurology (Chicago). 29, 253-257. 
Farrell, D. F., Percy, A. K., Kaback, M. M., and McKhann, G. M. (1973a). Globoid cell Krabbe's leukodystrophy: heterozygote detection in cultured skin fibroblasts. American Journal of Human Genetics, 25, 604-609.

Farrell, D. F., Baker, H. J., Herndon, R. M., Lindsey, J. R., and McKhann, G. M. (1973b). Feline $\mathbf{G}_{M 1}$ gangliosidosis: biochemical and ultrastructural comparisons with the disease in man. Journal of Neuropathology and Experimental Neurology, 32, 1-18.

Kaback, M. M., and Howell, R. R. (1970). Infantile metachromatic leukodystrophy: heterozygote detection in skin fibroblasts and possible applications to intrauterine diagnosis. New England Journal of Medicine, 282, 1336-1340.

Kurczynski, T., Fletcher, T. F., and Suzuki, K. (1976). Lactosylceramidases in canine globoid leukodystrophy. Transactions of the American Society of Neurochemistry, 7, 195.

LeRoy, J. G., Van Elsen, A. F., Martin, J. J., Dumon, J. E. Hulet, A. E. Okacla, S., and Navarro, C. (1973). Infantile metachromatic leukodystrophy: confirmation of a prenatal diagnosis. New England Journal of Medicine, 288, 1365-1369.

Okada, S., and O'Brien, J. S. (1969). Tay-Sachs disease: generalized absence of a $\beta$-D-N-acetylhexosaminidase component. Science, 165, 698-700.

Percy, A. K., McCormick, U. M., Kaback, M. M., and Herndon, R. M. (1973). Ultrastructure manifestations of $\mathbf{G}_{\mathrm{M}_{1}}$ and $\mathbf{G}_{\mathrm{M} 2}$ gangliosidosis in fetal tissues. Archives of Neurology (Chicago), 28, 417-419.

Shaw, C. M.. and Carlson, C. B. (1970). Crystalline structures in globoid-epitheloid cells: an electron microscopic study of globoid leukodystrophy (Krabbe's disease). Journal of Neuropathology and Experimental Neurology, 23, 306-319.

Suzuki, K., and Grover, W. D. (1970). Krabbe's leukodystrophy (globoid cell leukodystrophy). Archives of Neurology (Chicago), 22, 385-396.

Suzuki, K., and Suzuki, Y. (1970). Globoid cell leuko- dystrophy (Krabbe's disease): deficiency of galactocerebroside $\beta$-galactosidase. Proceedings of the National Academy of Sciences of the United States, 66, 302-309.

Suzuki, Y., and Suzuki, K. (1971). Krabbe's globoid cell leukodystrophy: deficiency of galactocerebrosidase in serum, leukocytes, and fibroblasts. Science, 171, 73-75.

Suzuki, K., Schneider, E. L., and Epstein, C. J. (1971). In utero diagnosis of globoid cell leukodystrophy (Krabbe's disease). Biochemical and Biophysical Research Communications, 45, 1363-1366.

Svennerholm, L., Hakansson, G., and Vanier, M. T. (1975).Chemical pathology of Krabbe's disease IV. Studies of galactosylceramide and lactosylceramide $\beta$-galactosidase in brain, white blood cells, and amniotic fluid cells. Acta Paediatrica Scandinavica, 64, 649-656.

Tanaka, H., and Suzuki, K. (1975). Lactosylceramide $\beta$-galactosidase in human sphingolipidosis: evidence for two genetically distinct enzymes. Journal of Biological Chemistry, 250, 2324-2332.

Van der Hagen, C. B., Børresen, A. L., Molne, K., Oftedal, G. Bjøro, K., and Berg, K. (1973). Metachromatic leukodystrophy 1 . Prenatal detection of arylsulphatase A deficiency. Clinical Genetics, 4,0 : 256-259.

Wenger, D. A., Sattler, M., Clark, C., and McKelveyD H. (1974). An improved method for the identifica tion of patients and carriers of Krabbe's disease Clinica Chemica Acta, 56, 199-206.

Wenger, D. A., Sattler, M., and Clark, C. (1975)尺 Effect of bile salts on lactosylceramide $\beta$-galactoe sidase activities in human brain, liver and culture skin fibroblasts. Biochimica et Biophysica Acta, 409 297-303.

Yunis, E. J., and Lee, R. E. (1969). The ultrastructure of globoid (Krabbe) leukodystrophy. Laboratory Investigation, 21, 415-419. 